\title{
Greenhouse and High Tunnel Production of Specialty Cut Flowers
}

\author{
Samantha R. Nobes ${ }^{1}$, Karen L. Panter ${ }^{1}$, and Randa Jabbour ${ }^{1}$
}

Additional index wORds. Calendula officinalis, Celosia argentea, cockscomb, Daucus carota, Helichrysum bracteatum, high altitude, local production, Matthiola incana, ornamental carrot, pot marigold, regional production, stock, strawflower

SUMMARY. The objective of this study was to determine best production practices for five different specialty cut flower species at an altitude of $7200 \mathrm{ft}$. Region-specific information about cut flower production is important because of unique environmental conditions. We grew five specialty cut flower species in two different growing environments: a greenhouse and a high tunnel. Flowers were grown yearround in the greenhouse and during late spring through fall in the high tunnels. We also used pinching as another production method for the potential increase in branching. The goals were to test the effects of species, growing environment, and pinching on the days from sowing to harvest, stem length, number of stems cut per plant, and marketable yield. Experiments were conducted at the University of Wyoming Laramie Research and Extension Center in Laramie, WY, to assess the potential for producing specialty cut flowers for local consumption. The species used in this study included 'Princess Golden' pot marigold (Calendula officinalis), 'Lucinda Mix' stock (Matthiola incana), 'Double Mix' strawflower (Helichrysum bracteatum), 'Dara' ornamental carrot (Daucus carota), and 'Celway Mix' cockscomb (Celosia argentea). Results showed significant species $\times$ environment and season interactions, indicating the importance of species and production practice selections. We successfully sold the cut flowers to the university student farm for community-supported agriculture shares and farm market sales, as well as to a local florist for use in floral arrangements. This study concluded that careful species selection for season and growing environment is essential for the successful integration of these niche cut flowers into current or future greenhouse and hightunnel production in Wyoming.

$\mathrm{T}$ he production of specialty cut flowers is an opportunity to add valuable products to $\mathrm{Wyo}^{-}$ ming growers and their local economy. The specialty cut flower market is growing in the United States as more cut flowers are being produced

Received for publication 21 May 2021. Accepted for publication 21 Sept. 2021.

Published online 15 October 2021

${ }^{1}$ Department of Plant Sciences, Department 3354, University of Wyoming, 1000 East University Avenue, Laramie, WY 82071

Funds for this project were provided through the Wyoming Department of Agriculture and Natural Resources and the U.S. Department of Agriculture Specialty Crop Block Grant Program. This work was made possible by a Specialty Crop Grant from the Wyoming Department of Agriculture.

S.R.N. is a Graduate Student.

K.L.P. is a Horticulture Specialist.

R.J. is an Associate Professor.

K.L.P. is the corresponding author. E-mail: kpanter@uwyo.edu.

This is an open access article distributed under the CC BY-NC-ND license (https://creativecommons. org/licenses/by-nc-nd/4.0/).

https://doi.org/10.21273/HORTTECH04894-21 regionally for local markets (Ortiz et al., 2012). The reasoning behind the increase in regional production is that specialty cut flowers cannot withstand long transportation distances and may have a shorter postharvest life (Ortiz et al., 2012). An increased interest in domestic production has led to the need for region- and crop-specific information about best production practices to increase the local production potential and gain information about the unique environmental conditions (Lamont, 2009; Ortiz et al., 2012).

Open-field production of cut flowers occurs in areas where yearround production is feasible, such as Hawaii, Florida, and California (Bonarriva, 2003). Cut flower production in short-season, high-altitude environments, like Wyoming, requires protection from potential frosts, high winds, and large day-to-night temperature swings. Greenhouse and high-tunnel production are potential ways to provide season extension and quality protection in the harsh Wyoming climate. Current research has evaluated comparisons between the field and hightunnel production of specialty cut flowers (Ortiz et al., 2012; Owen et al., 2016) or focused on a single production environment (Dole et al., 2016; Wien, 2009). However, we did not find current research comparing greenhouse to high-tunnel production for specialty cut flowers.

Greenhouse production is a popular system for producing cut flowers and provides an environment where sequential plantings can supply cut flowers that are in demand year-round (Kaiser and Ernst, 2016). Hightunnel production has become an increasingly popular way for large-scale and small-scale growers to diversify and market products directly to consumers. High tunnels are used for season extension, increasing yield, and improving the quality of crops, such as cut flowers (Lamont, 2009; Wien, 2009). The protection from inclement weather using both of the production methods has shown to increase cut flower stem lengths and prevent chances of disfigurement and disease (Lamont, 2009). Productivity in protected environments needs to be evaluated regionally (Ortiz et al., 2012). To date, there have been two studies

\begin{tabular}{llll}
\hline $\begin{array}{l}\text { Units } \\
\text { To convert U.S. to SI, } \\
\text { multiply by }\end{array}$ & U.S. unit & SI unit & $\begin{array}{l}\text { To convert SI to U.S., } \\
\text { multiply by }\end{array}$ \\
\hline 0.3048 & $\mathrm{ft}$ & $\mathrm{m}$ & 3.2808 \\
0.0929 & $\mathrm{ft}^{2}$ & $\mathrm{~m}^{2}$ & 10.7639 \\
3.7854 & gal & $\mathrm{L}$ & 0.2642 \\
2.54 & inch $(\mathrm{es})$ & $\mathrm{cm}$ & 0.3937 \\
10.7639 & lumen $(\mathrm{s}) / \mathrm{ft}^{2}$ & $\mathrm{~lx}$ & 0.0929 \\
0.0254 & $\mathrm{mil}(\mathrm{s})$ & $\mathrm{mm}$ & 39.3701 \\
28.3495 & $\mathrm{Oz}$ & $\mathrm{g}$ & 0.0353 \\
7.4892 & $\mathrm{Oz} / \mathrm{gal}$ & $\mathrm{g} \cdot \mathrm{L}^{-1}$ & 0.1335 \\
0.001 & $\mathrm{ppm}$ & $\mathrm{g} \cdot \mathrm{L}^{-1}$ & 1000 \\
1 & $\mathrm{ppm}$ & $\mathrm{mg} \cdot \mathrm{L}^{-1}$ & 1 \\
$\left({ }^{\circ} \mathrm{F}-32\right) \div 1.8$ & ${ }^{\circ} \mathrm{F}$ & ${ }^{\circ} \mathrm{C}$ & $\left({ }^{\circ} \mathrm{C} \times 1.8\right)+32$ \\
& & &
\end{tabular}

Horflechnology $\cdot$ December $202131(6)$ 
in Wyoming of fresh cut sunflower (Helianthus annuus) production (Garfinkel and Panter, 2014; Panter et al., 2019). Garfinkel and Panter (2014) demonstrated the successful cultivation of three cultivars of sunflower in yearround greenhouse production. Panter et al. (2019) showed that high-tunnel orientation did not affect sunflower growth parameters such as stem lengths and time to harvest and that the differences were the result of specific cultivar characteristics.

Many different species can be grown for cut flower use with the main goal of sufficient production possible under the local conditions. Accordingly, we used five different specialty cut flower species to determine best practices for growing in greenhouses and high tunnels. Flowers were selected to span a range of types and families that could add diversity for Wyoming growers. We also looked at a one-time pinching method for the potential increase in branching. The objective was to quantify the differences in stem length and days to harvest for the five species under these production practices. The goal of the project was to produce information for Wyoming growers and demonstrate whether growing a diversity of fresh cut flowers is achievable.

\section{Materials and methods \\ Site background}

Greenhouse and high tunnel experiments were conducted at the University of Wyoming Laramie Research and Extension Center greenhouse complex. The facility is located in Laramie, WY (lat. $44^{\circ} 45^{\prime} 30^{\prime \prime} \mathrm{N}$, long. $108^{\circ} 46^{\prime} 36^{\prime \prime} \mathrm{W}$, elevation $7200 \mathrm{ft})$.

\section{Greenhouse and high tunnel specifications}

The greenhouse was $\approx 2000 \mathrm{ft}^{2}$, covered in a single roof, and had double-walled sides made of polycarbonate glazing (Fig. 1). The greenhouse was actively controlled by a combination of venting, heating, and cooling technologies (Johnson Controls, Milwaukee, WI, and Wadsworth Control Systems, Arvada, CO). The rolling metal mesh growing bench was oriented east to west and aligned from north to south; it measured $\approx 6 \times 16 \mathrm{ft}$. The temperature set points were 70 / $60{ }^{\circ} \mathrm{F}$ (day/night). Garfinkel and Panter (2014) collected environmental

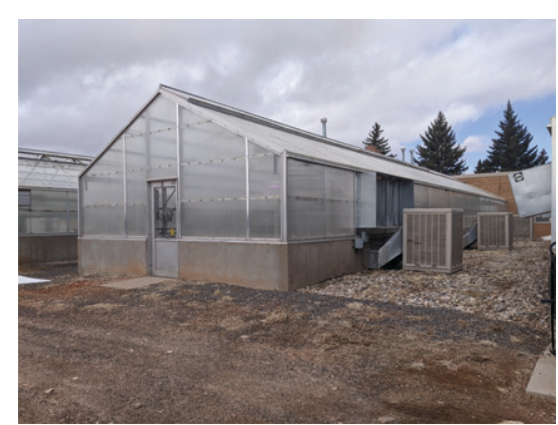

Fig. 1. The greenhouse with a single roof and double-walled sides made of polycarbonate glazing. The greenhouse was $\approx 2000 \mathrm{ft}^{2}\left(185.8 \mathrm{~m}^{2}\right)$, had a single roof, and had double-walled sides made of polycarbonate glazing. The greenhouse was used for containerized specialty cut flower production of five different specialty cut flower species. The greenhouse is located at the University of Wyoming Laramie Research and Extension Center in Laramie, WY.

data inside the greenhouse using pendant temperature/light data loggers (64K-UA-002-64 HOBO; Onset Computer Corp., Bourne, MA) to track light intensity and air temperature over a 13-month period. The data loggers were placed $52 \mathrm{~cm}$ above the benches and found that average temperatures ranged from 66.6 to $67.9^{\circ} \mathrm{F}$ and average light readings were 1639.4 to 2648.4 lumens/ $/ \mathrm{ft}^{2}$ (Garfinkel and Panter, 2014).

Two high tunnels were used, one oriented east to west and one oriented north to south (Solar Star Greenhouse; Growers Supply, Dyersville, IA) (Fig. $2)$. The high tunnels were $12 \times 16 \mathrm{ft}$ and had an arch-style roof. They were

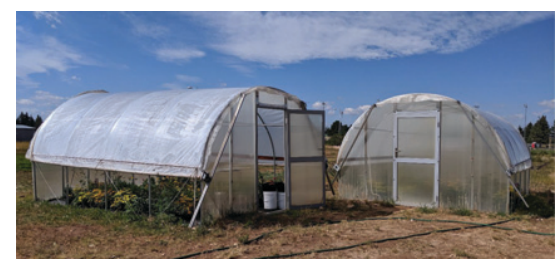

Fig. 2. Two high tunnels covered in a double layer of $6-\mathrm{mil}(0.15 \mathrm{~mm})$ uninflated polyethylene plastic with double-walled polycarbonate for each end wall and manual roll-up sides. The high tunnels were used for containerized production of five different specialty cut flower species. Each is $12 \times 16 \mathrm{ft}(3.7 \times 4.9 \mathrm{~m})$. The high tunnels are located at the University of Wyoming Laramie Research and Extension Center in Laramie, WY. covered in a double layer of 6-mil uninflated polyethylene plastic with doublewalled polycarbonate for each end wall. Both tunnels used manual roll-up sides up to $\approx 3 \mathrm{ft}$ from ground level to provide ventilation control. High-tunnel sides were kept open when temperatures increase above $40{ }^{\circ} \mathrm{F}$; they were closed when temperatures decreased below $40{ }^{\circ} \mathrm{F}$. All plants were grown under natural light and daylengths in the greenhouse and high tunnels. Panter et al. (2019) obtained environmental data inside of the high tunnels from 2012 through 2015. The temperature and light data loggers were positioned 12 inches above the ground; the average air temperature ranged from 65.5 to $79.5^{\circ} \mathrm{F}$; light readings were higher than those in the greenhouse and differed depending on the time of day (ranging between 0 and $\approx 11,984.5$ lumens $/ \mathrm{ft}^{2}$ ) (Panter et al., 2019).

\section{Cut flowers}

Flowers were grown and harvested over three growing seasons: Summer 2018, Winter 2018-19 (greenhouse only), and Summer 2019. The species used in this study included 'Princess Golden' pot marigold (Calendula officinalis), 'Lucinda Mix' stock (Matthiola incana), 'Double Mix' strawflower (Helichrysum bracteatum), 'Dara' ornamental carrot (Daucus carota), and 'Celway Mix' cockscomb (Celosia argentea) (Harris Seeds, Rochester, NY). Flowers were selected to span a range of types and families that could add diversity for Wyoming growers.

\section{Experimental design}

The experiment was conducted in both greenhouse and high-tunnel environments. The greenhouse component was replicated over two summer growing seasons (2018 and 2019) and one winter growing season (2018-19). The high-tunnel component was conducted during Summer 2018 and Summer 2019. Six containers of each species were arranged within experimental blocks. Each block consisted of three single-plant replicates of each species randomly arranged in a $3 \times 10$ grid; each container contained one plant. Three of the six single-plant replicates were pinched while the other three single-plant replicates of each species were unpinched. We assigned each test plant a number one through three and "P" or "U" for pinched or 


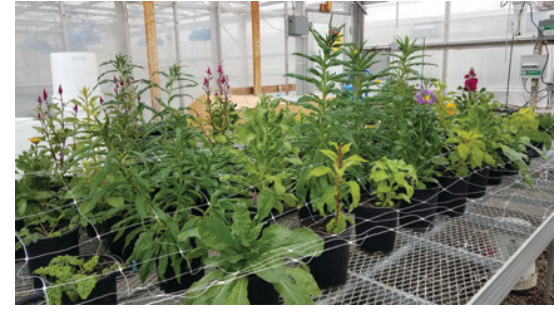

Fig. 3. Example of an experimental block with a $3 \times 10$ grid with an edge row on a mesh bench inside the greenhouse. The rolling metal mesh growing bench was oriented east-west and aligned north-south; it measured $\approx 6 \times 16 \mathrm{ft}(1.8 \times 4.9 \mathrm{~m})$. The experimental block consists of five cut flower species: pot marigold, cockscomb, ornamental carrot, strawflower, and stock. Each species has six individual potted plants; three are pinched and three remained unpinched, with the exception of stock that only has unpinched plants. Image also shows the edge row of flower species around the experimental block.

unpinched; then, we randomly placed them in rows with $\mathrm{l}-\mathrm{ft}$ spacing. Zinnia (Zinnia elegans and Zinnia hybrida) and extras of the cut flower species were placed as an edge row around the perimeter of each experimental block to mitigate edge affects. One experimental block, arranged as described, was placed in the greenhouse environment (Fig. 3). Four experimental blocks were placed in the high-tunnel environment (two per high tunnel) (Figs. 4 and 5). Blocking was used in the high tunnels to account for environmental variability with minor differences based on location within the high tunnel. We placed blocks in the same design as used in previous studies

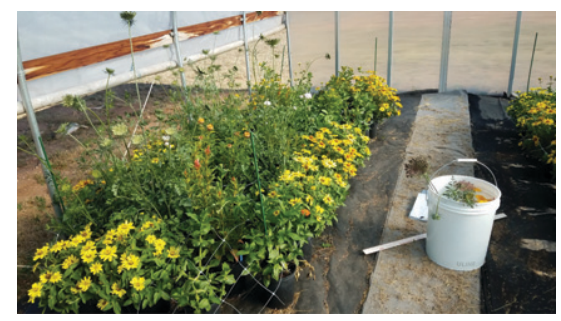

Fig. 4. Example of an experimental block inside a high tunnel. The experimental block consists of five cut flower species: pot marigold, cockscomb, ornamental carrot, strawflower, and stock. Each species has six individual potted plants; three are pinched and three remained unpinched, with the exception of stock that only has unpinched plants.

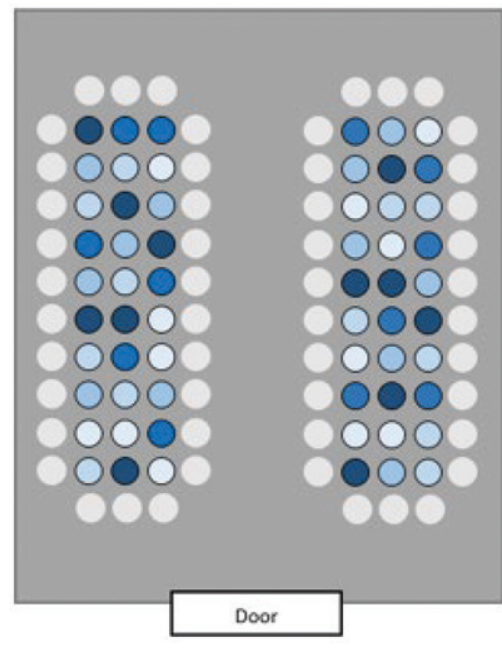
- pot marigold
- cockscomb
ornamental carrot
O strawflower
o stock

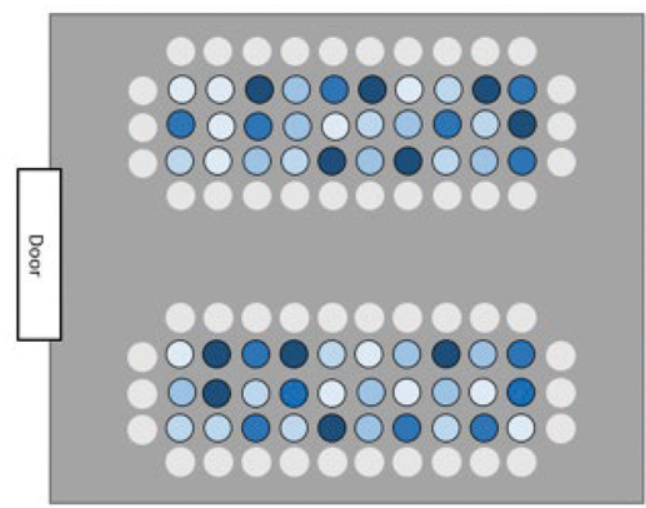

Fig. 5. Example of the high-tunnel block layout with one block per side with a middle aisle. Gray circles represent the edge row of zinnias. The experimental block consists of five cut flower species: pot marigold, cockscomb, ornamental carrot, strawflower, and stock. Each species has six individual potted plants; three are pinched and three remained unpinched, with the exception of stock that only has unpinched plants.

in this location for cut sunflowers and fresh herbs (Panter et al., 2019). The unequal number of plants in the greenhouse as compared with the high tunnel was the result of limited feasibility and logistical challenges with space for the greenhouse aspect of the study.

\section{Propagation}

Seeds were sown into 128-cell plug trays filled with a commercial germination medium (Seed Germination Mix; Conrad Fafard, Agawam, MA) and placed on a misting bench in the greenhouse. For summer production, seeds were sown in April; for winter production, seeds were sown in September (Table 1). The misting bench was set with temperatures at $70 / 65^{\circ} \mathrm{F}$ (day/night). Misting was controlled by an automated clock system (Schaefer Solar 3B; Schaefer Ventilation Equipment, Sauk Rapids, MN). The mist system was activated on for $20 \mathrm{~s}$ for every 20 solar units collected, where one solar unit is equal to 0.02 $\mathrm{mol} \cdot \mathrm{m}^{-2}$.

\section{Production methods}

Seedlings were transplanted to \#1 containers $(0.75$-gal $)$ that were filled with a commercial soilless medium containing coarse-grade peatmoss and perlite, bark, dolomitic and calcitic limestone, and a nonionic wetting agent (BM7 bark mix; Berger, Saint-Modeste, QC, Canada). Seedlings were transplanted $\approx 3$ to 4 weeks after sow dates (Table 1 ). Each pot had one plant, and all were moved to the appropriate high tunnel or kept in the greenhouse on the day of transplantation. Containers in the greenhouse and high tunnel were watered by hand daily until water drained from the bottom of each container. Watering occurred once in the morning and once in the afternoon, or as needed based on weather and growth stage considerations. Fertilization occurred starting 7 to $14 \mathrm{~d}$ after transplantation using a $1: 100$ injector and 5-gal concentrate bucket of $15 \mathrm{~N}-2.2 \mathrm{P}-12.5 \mathrm{~K}$ liquid 
Table 1. Sow dates, transplanting dates, and pinching dates for pot marigold, cockscomb, ornamental carrot, strawflower, and stock during Summer 2018, Winter 2018-19, and Summer 2019. We did not pinch stock plants in Winter 2018-19 or Summer 2019 growing seasons because of pinching not allowing for regrowth.

\begin{tabular}{|c|c|c|c|c|c|c|c|c|c|}
\hline \multirow[b]{2}{*}{ Species } & \multicolumn{3}{|c|}{ Sow date } & \multicolumn{3}{|c|}{ Transplanting date } & \multicolumn{3}{|c|}{ Pinch date } \\
\hline & $\begin{array}{c}\text { Summer } \\
2018\end{array}$ & $\begin{array}{c}\text { Winter } \\
\text { 2018-19 }\end{array}$ & $\begin{array}{c}\text { Summer } \\
2019\end{array}$ & $\begin{array}{c}\text { Summer } \\
2018\end{array}$ & $\begin{array}{c}\text { Winter } \\
\text { 2018-19 }\end{array}$ & $\begin{array}{c}\text { Summer } \\
2019\end{array}$ & $\begin{array}{c}\text { Summer } \\
2018\end{array}$ & $\begin{array}{c}\text { Winter } \\
\text { 2018-19 }\end{array}$ & $\begin{array}{c}\text { Summer } \\
2019 \\
\end{array}$ \\
\hline Cockscomb & 4 Apr. & 4 Sept. & 1 Apr. & 1 May & 26 Sept. & 28 May & 30 May & 21 Oct. & 19 June \\
\hline Ornamental carrot & 4 Apr. & 4 Sept. & 1 Apr. & 1 May & 26 Sept. & 28 May & 23 May & 21 Oct. & 19 June \\
\hline Strawflower & 4 Apr. & 4 Sept. & 1 Apr. & 1 May & 26 Sept. & 28 May & 23 May & 21 Oct. & 19 June \\
\hline
\end{tabular}

fertilizer (Jack's 15-5-15; JR Peters, Allentown, PA) to provide (in ppm) 150 nitrogen $(\mathrm{N}), 22$ phosphorus $(\mathrm{P})$, and 125 potassium $(\mathrm{K})$. Fertigation was performed with each irrigation Mondays through Fridays. Clear water was used for irrigation on Saturdays and Sundays. We also used a topdressing of $2.5 \mathrm{~g}$ of $15 \mathrm{~N}-4.4 \mathrm{P}-9.9 \mathrm{~K}$ controlled-release fertilizer (Osmocote Plus 15-9-12, 5- to 6-month formula; ICL Specialty Fertilizers, Summerville, SC). Plants in the greenhouse and high tunnel were staked and caged $14 \mathrm{~d}$ after transplantation. Plant stems were supported with plastic floral caging that was installed horizontally, with four main stakes placed in the outside corner containers for reinforcement. The caging was raised throughout the study to help ensure straight stems (Armitage and Laushman, 2008; Dole and Wilkins, 1999).

\section{Pinching}

Three plants from each species per block were soft-pinched on the main stem after transplantation. We pinched to remove the growing point with our thumb and forefinger at the early seedling stage after the plants had developed three nodes. Three plants of each species remained unpinched. We tested pinching across species and environment as a potential way to stimulate branching and increase flower production. In Summer 2018, we included three pinched and three unpinched stock plants; this was in contrast to Winter 2018-19 and Summer 2019, when we only included three unpinched stock plants. Stock plants remained unpinched because they did not continue to grow once pinched. Plants were pinched 3 to 4 weeks after transplantation (Table 1).

\section{Harvest and data collection}

We harvested flowers every $2 \mathrm{~d}$ in the mornings throughout each growing season. For the spike-form and umbel flowers (cockscomb, stock, and ornamental carrot), the rule of thirds was used for harvest guidelines: when onethird of the florets were fully open, when one-third were showing bud in color, and when one-third were in bud (Armitage and Laushman, 2008) (Fig. 6). Pot marigold were considered ready to harvest when the outer ring of ray florets had opened (Clark et al., 2010), and strawflower were considered ready when the outermost layer of bracts had opened and the centers were barely visible (Jauron, 2003) (Fig. 6). Stems were cut to ensure that there were at least three nodes left behind on main stems to ensure more growth, and stem length was immediately recorded. Stem length was measured from the base of the cut to the base of the flower head receptacle. Cut stems were placed in a bucket with water and a citric acid-concentrated flower food at $10 \mathrm{~g} \cdot \mathrm{L}^{-1}$ (Floralife Cut Flower Food; Smithers-Oasis Co., Walterboro, SC) immediately after being cut; they were stored in a walk-in cooler set to $40{ }^{\circ} \mathrm{F}$. Data were also collected regarding the time to harvest from sowing (days). Cut flower producers consider stems marketable when the minimum stem length is between 30 and $41 \mathrm{~cm}$ (Koch, 1996; Verlinden and McDonald, 2007). All of the stems from each test plant within each block were used to record the number of marketable stems based on stem length (we used $30 \mathrm{~cm}$ as the minimum), mean stem lengths, and mean days to harvest from sowing.

\section{Statistical analysis}

Analysis and statistical computations of data were performed using general linear model procedures in SAS (version 9.3 or 9.4 ; SAS Institute; Cary, NC). Means separations were conducted using the least-square means procedure adjusted with the Tukey-Kramer test at $\alpha=0.05$ for the individual species. Separate models were constructed for effects on stem length, days to harvest, and stems per plant. Models for stem length and days to harvest included data from all of the stems cut during each growing season for each species per greenhouse or high-tunnel environment. Stems per plant were calculated using the number of stems for each potted plant. Marketable yields were calculated by dividing the number of stems of $30 \mathrm{~cm}$ or more by the total number of cut stems for each species.

We conducted two overall sets of data analyses. The first set of analyses tested for effects of the environment (greenhouse and high tunnel), species (pot marigold, cockscomb, ornamental carrot, strawflower, and stock), pinching (pinched and unpinched), and environment $\times$ species $\times$ year interactions. Winter 2018-19 data were not included in this first set of analyses comparing environments because we only had greenhouse data, not high-tunnel data, for this season.

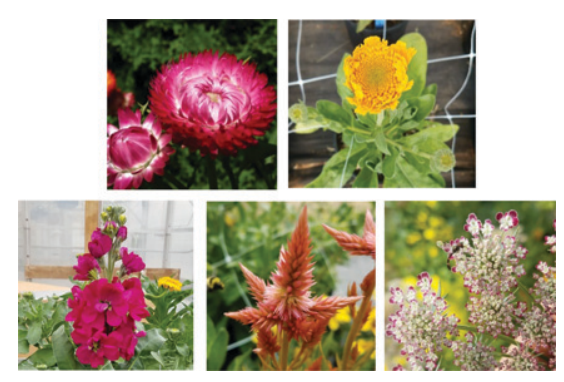

Fig. 6. Example of each specialty cut flower species when they are ready to be harvested. Top left to right: 'Double Mix' strawflower and 'Princess Golden' pot marigold. Bottom left to right: 'Lucinda Mix' stock, 'Celway Mix' cockscomb, and 'Dara' ornamental carrot. 
The second set of analyses included only greenhouse production data from Summer 2018, Winter 2018-19, and Summer 2019. Models tested for the effect of season (summer and winter), species (pot marigold, cockscomb, ornamental carrot, strawflower, and stock), pinching (pinched and unpinched), and season $\times$ species interactions. Extremely limited data were collected from stock caused by only one stem being produced per plant and the pinching treatment not allowing for regrowth. Therefore, the sample size of stems analyzed was far lower and resulted in an imbalanced design. Stock data were used separately in the same type of model.

\section{Results and discussion Effect of growing environment during summer production}

ENVIRONMENT: STEM LENGTH. Stem length differed according to a significant species $\times$ environment and year interaction (Fig. 7A). Pot marigold had longer stem lengths in the Summer 2018 growing season for both environments compared with Summer 2019. Pot marigold reached $37.4 \mathrm{~cm}$ on average in the greenhouse in 2018 , and $31.1 \mathrm{~cm}$ in 2019 . In the high tunnels, pot marigold had an average stem length of $34.8 \mathrm{~cm}$ in 2018; in 2019, the average stem length was $29.5 \mathrm{~cm}$. Cockscomb had a significant difference in the 2018 season: it grew longer stems in the greenhouse than in the high tunnels ( 31.8 to $26.2 \mathrm{~cm}$, respectively). Ornamental carrot was the only species to have longer stem lengths in the high tunnels as compared with the greenhouse in both seasons; in 2018, the lengths were $29 \mathrm{~cm}$ in the greenhouse and $42.4 \mathrm{~cm}$ in the high tunnels. A similar result happened in 2019, with an average length of $35 \mathrm{~cm}$ in the greenhouse and $45 \mathrm{~cm}$ in the high tunnels. Strawflower had longer stem lengths by $\approx 5 \mathrm{~cm}(33.8$ to $39.1 \mathrm{~cm})$ in the greenhouse during the 2018 season. During 2018, strawflower reached an average stem length of $39 \mathrm{~cm}$ in the greenhouse and $33.8 \mathrm{~cm}$ in the high tunnels. The 2018 lengths in the high tunnel were longer than those during the 2019 season by $\approx 2.5 \mathrm{~cm}(33.8$ and $31.2 \mathrm{~cm}$, respectively). Stock significantly differed between environments in 2019; on average, $40 \mathrm{~cm}$ was reached in the greenhouse, and 29.7 $\mathrm{cm}$ was reached in the high tunnels.
$\mathbf{A}$

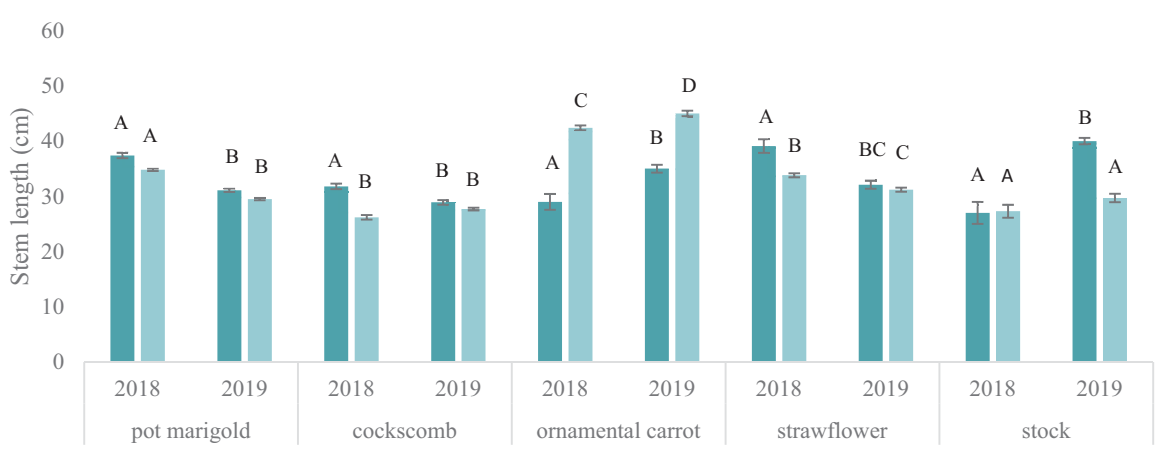

B
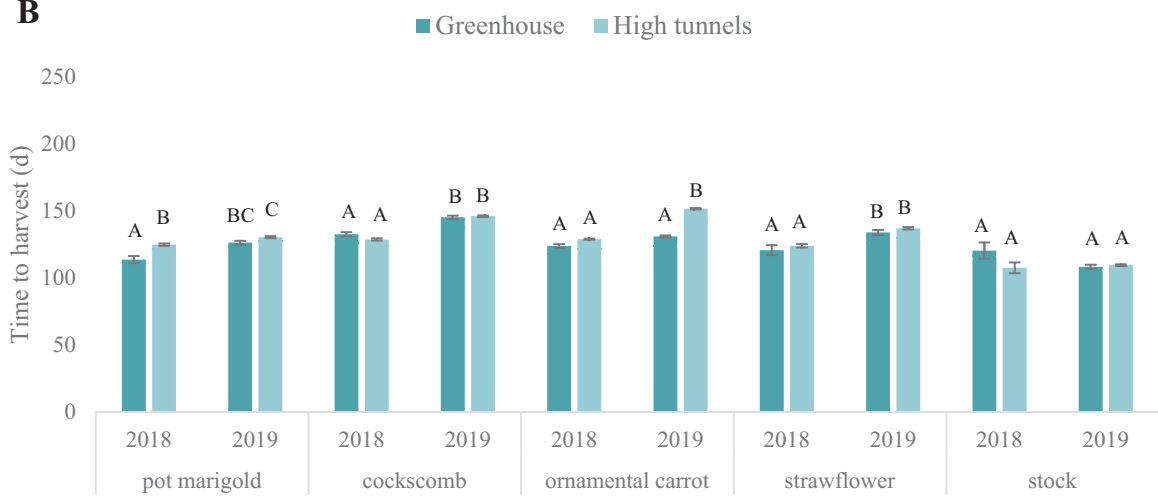

C

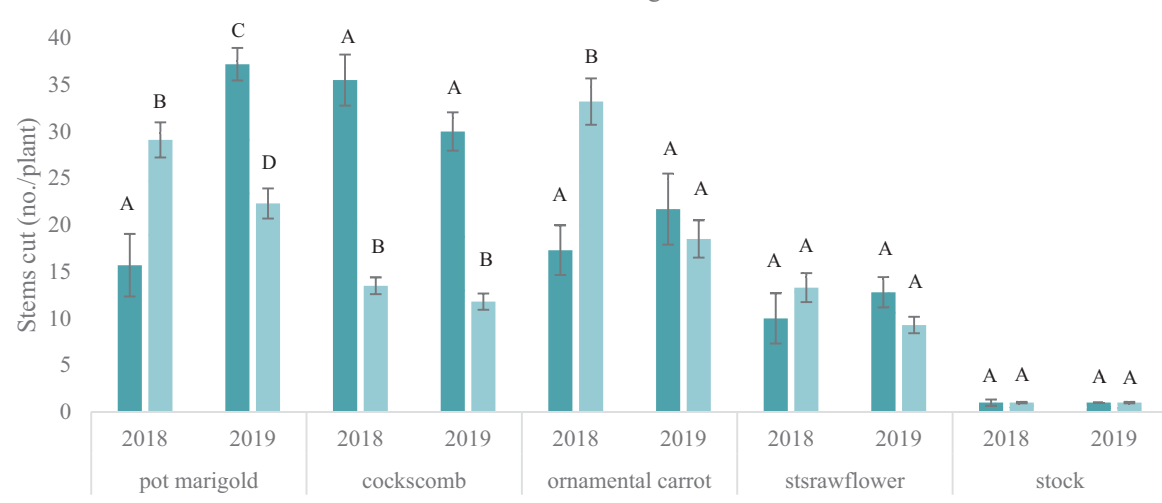

Fig. 7. Mean stem lengths (A), days from seed sowing to harvest (B), and stems cut per plant $(\mathrm{C})$ of cut flower species from both summer growing seasons in a greenhouse and high tunnels. Error bars represent SE. Mean comparisons were conducted within each individual species using pairwise comparisons from Tukey test. Means followed by the same letter are not statistically different at $P \leq 0.05$; $1 \mathrm{~cm}=0.3937$ inch.

We also looked at the distribution of stem lengths for each species between environments and years; none of the species had $75 \%$ of their distribution with a stem length more than $30 \mathrm{~cm}$ (Table 2). Distributions can be used by growers to determine whether a species would be feasible for a certain type of market. A grower that direct-markets at farmers' markets may be more successful than a grower marketing direct to florist based on the amount of stems they will get that are under the $30-\mathrm{cm}$ threshold.

Several production parameters other than environment can affect the mean stem lengths, such as species selection, transplanting vs. direct seeding, and photoperiod. Chopde et al. (2015) found that spacing influences lengths were recorded with $15-\times 10$ $\mathrm{cm}$ spacing as opposed to $30-\times 30-\mathrm{cm}$ spacing in field production. Some pot marigold stem length; longer stem 
Table 2. Distributions of stem lengths for five containerized specialty cut flower species among environments (greenhouse and high tunnel), seasons (summer and winter), and years (2018 and 2019).

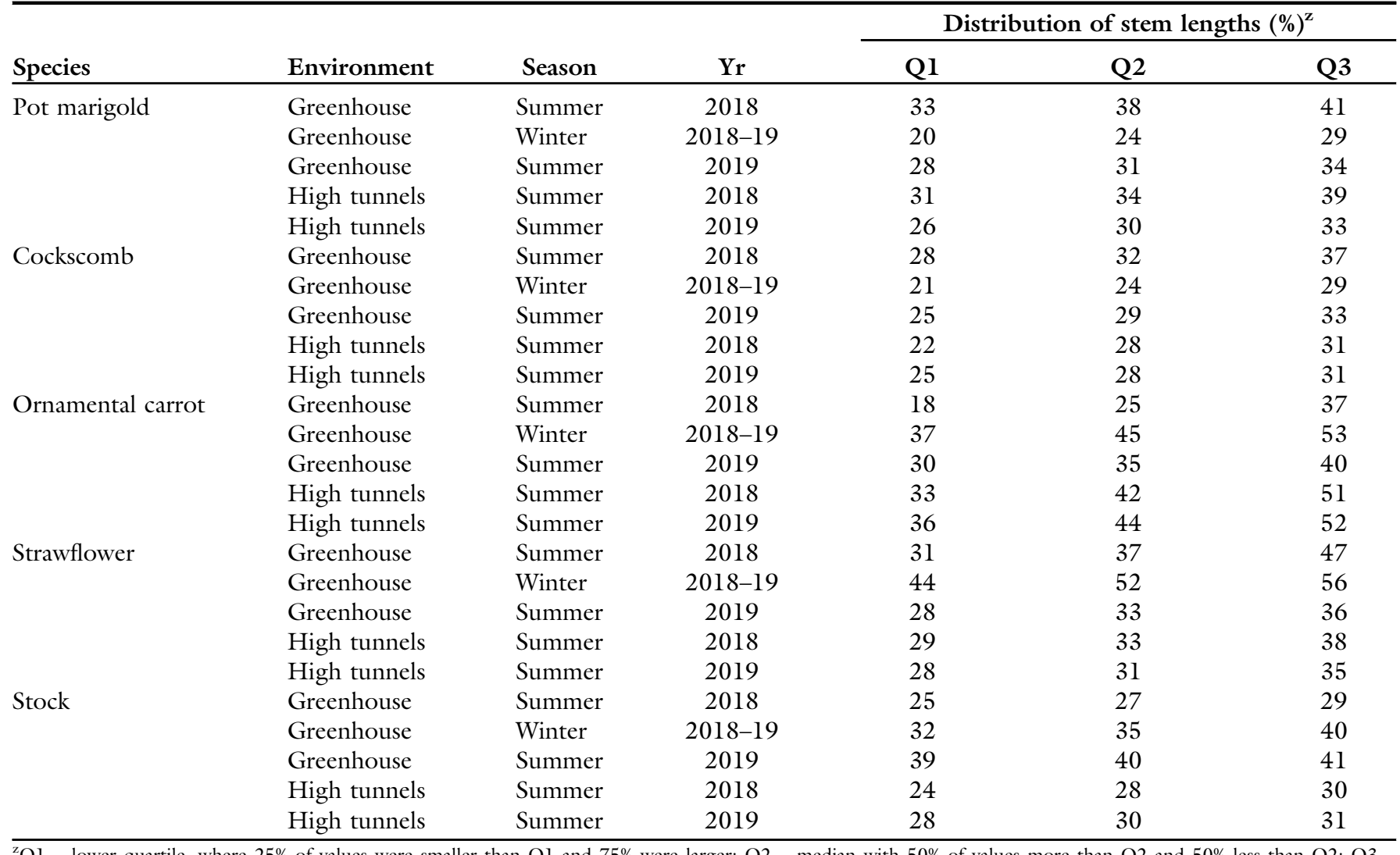

${ }^{\mathrm{z}} \mathrm{Q} 1=$ lower quartile, where $25 \%$ of values were smaller than $\mathrm{Q} 1$ and $75 \%$ were larger; $\mathrm{Q} 2=$ median with $50 \%$ of values more than $\mathrm{Q} 2$ and $50 \%$ less than $\mathrm{Q} 2 ; \mathrm{Q} 3=$ upper quartile, where $75 \%$ of values were smaller than Q3 and $25 \%$ were larger.

cockscomb cultivars had longer stem lengths when produced in high tunnels compared with those produced in the field (Ortiz et al., 2012; Owen et al., 2016). We found that 'Celway' cockscomb had longer stem lengths with greenhouse production than with high-tunnel production. 'Dara' ornamental carrot produced longer stems in the high tunnels. Dole et al. (2016) found that there is a trade-off between stem length and number of stems cut per plant; harvesting many stems will lead to shorter stems over the season. Differences seen in stock stem lengths may have occurred because of differences in temperatures and photoperiods. The Lucinda series that we used is a midseason cultivar that is recommended for greenhouse production (Armitage and Laushman, 2008). Wien (2008) suggested using early cultivars of stock for high-tunnel production or earlier planting of late cultivars. Pinching was not a major driver for the mean stem lengths and is not a recommended production method for these species.
Summer growing seasons in the Rocky Mountain West have highintensity sunlight, especially at higher elevations (Curtis and Grimes, 2004). Crops in high tunnels and greenhouses receive a lower daily light integral and reduced air movement compared with those in the field, which often results in significantly longer stems (Torres and Lopez, 2010; Wien, 2009; Wien and Pritts, 2009). The type of market and market demand will influence a grower's target stem length. Generally, our production methods led to an average stem length that met our $30-\mathrm{cm}$ threshold; we had longer stem lengths in the greenhouse, with the exception of ornamental carrot.

ENVIRONMENT: DAYS TO HARVEST. Days to harvest from sowing differed according to a significant species $x$ environment and year interaction for all species except stock (Fig. 7B). Pot marigold harvest differed between the environments in 2018, with harvest occurring $\approx 1 \mathrm{l} \mathrm{d}$ earlier, on average, in the greenhouse than in the high tunnels (113.8 and $124.9 \mathrm{~d}$, respectively).
Pot marigold had fewer days to harvest in the greenhouse in 2018 compared with 2019 (113.8 and $126.4 \mathrm{~d}$, respectively). The same tendency occurred in the high tunnels. In 2018, the average days to harvest was $124.9 \mathrm{~d}$; in 2019 , the average days to harvest was 130.5 d. Days to harvest of cockscomb and strawflower differed between years, but not between environments. For cockscomb, the 2018 greenhouse mean days to harvest was $132.7 \mathrm{~d}$; for 2019 , it was $145.3 \mathrm{~d}$. There was a similar pattern in the high tunnels between 2018 and 2019 (128.8 and $146.1 \mathrm{~d}$, respectively). Strawflower also reached days to harvest more quickly in 2018 than in 2019 in both greenhouse (120.8 d in 2018 and $134 \mathrm{~d}$ in 2019) and hightunnel environments (124 d in 2018 and $137.1 \mathrm{~d}$ in 2019). In 2019, days to harvest of ornamental carrot significantly differed between the two environments (greenhouse: 131 d; high tunnels: $151.7 \mathrm{~d}$ ).

Time to harvest is important for production because it is tied to input and labor costs and provides access to 
earlier marketability (Ortiz et al., 2012). Fewer days to harvest generally occurred in the greenhouse. Containerized production can potentially reduce days to harvest compared with field production (Armitage and Laushman, 2008). Studies comparing field production to high-tunnel production show a reduced time to harvest for many different cut flower species in the high-tunnel environment (Ortiz et al., 2012; Owen et al., 2016). The information in this study may be useful to growers in this region when considering if a cut flower crop fits into their production area and schedule. It may also be useful in regions where field production is more common and could be compared by growers who want to gain access to season extension and earlier marketability. Pinching was not a significant predictor of mean days to harvest during the summer growing seasons, regardless of environment.

ENVIRONMENT: STEMS PER PLANT. The number of stems cut per plant differed according to a significant species $\times$ environment and year interaction (Fig. 7C). Pot marigold differed between the environments and years. During the Summer 2018 season, pot marigold had 15.7 stems cut per plant in the greenhouse and 29.1 stems/ plant in the high tunnels. In contrast, in 2019, more stems were cut per plant in the greenhouse compared with the high tunnels (37.2 and 22.3 stems/plant, respectively). Cockscomb differed consistently between the two environments in each season, with more stems cut in the greenhouse environment. During the Summer 2018 season, cockscomb had, on average, 35.5 stems cut per plant in the greenhouse and 13.5 in the high tunnels. Similarly, in $2019, \approx 18$ more stems were cut per plant, on average, in the greenhouse (11.8 to 30 stems/ plant). Ornamental carrot had more stems cut per plant in the high tunnels during the Summer 2018 season, with 33.2 compared with 17.3 in the greenhouse; however, this difference did not occur in 2019. Stock produced only one cut stem per plant in both environments. Some of the differences seen within species occurred because some plants had to be removed early; during Summer 2018, multiple pot marigolds and ornamental carrots had to be removed from the greenhouse because of virus problems. Pinching did not significantly affect stems cut per plant for any of the species.

Best production practices are species-dependent. Protected environments such as high tunnels have the ability to offer higher productivity in the form of more stems per week compared with field production for a cultivar of flower species (Wien, 2009). Ortiz et al. (2012) found that cockscomb produced more stems per $\mathrm{m}^{2}$ in high tunnels than in the field. We found that our cockscomb cultivar produced more stems per plant and had longer stem lengths in greenhouse production compared with high tunnel production. Other production practices such as transplanting need to be addressed as well. Dole et al. (2016) found that 'Dara' ornamental carrot produced more stems per plant when they were direct-seeded as opposed to when they are transplanted.

\section{Effect of season on greenhouse production}

SEASON: STEM LeNGTH. Stem length differed according to a significant species $\times$ season and year interaction for all species except stock (Fig. $8 \mathrm{~A})$. There were differences in stem length among growing seasons for all individual species. Pot marigold and cockscomb had longer stem lengths in the summers. Pot marigold had an average stem length of $37.4 \mathrm{~cm}$ in Summer 2018, $24.5 \mathrm{~cm}$ in Winter 2018-2019, and $31.1 \mathrm{~cm}$ in Summer 2019. Cockscomb had a similar pattern $(31.8,24.7$, and $28.9 \mathrm{~cm}$, respectively). Ornamental carrot and strawflower had longer stem lengths in the winter. Ornamental carrot had an average stem length of $29 \mathrm{~cm}$ in Summer 2018, 44.9 $\mathrm{cm}$ in Winter 2018-19, and $35 \mathrm{~cm}$ in Summer 2019. Strawflower had a similar pattern $(39,50.8$, and $32.1 \mathrm{~cm}$, respectively). Stock stem lengths were shorter in Summer 2018 than in the other two growing seasons, with an average of $27 \mathrm{~cm}$ in Summer 2018, $35.7 \mathrm{~cm}$ in Winter 2018-2019, and 40 $\mathrm{cm}$ in the Summer 2019.

All plants were grown under natural light intensity and daylength conditions for Laramie, WY. Seasonal differences had an overall impact on plant growth. Pot marigold is a facultative long-day plant and will flower earlier under long days, but it will still flower regardless of daylength. Cockscomb is a quantitative short-day plant, but it will flower at any photoperiod; they flower faster under photoperiods of $14 \mathrm{~h}$ or less (Armitage and Laushman, 2008). Strawflowers are not photoperiod-sensitive, but long days will contribute to faster flowering (Armitage and Laushman, 2008). Stock is more temperature-dependent; high temperatures will delay flowering in most cultivars and lower temperatures will promote flowering. Long days can partially substitute for cold in some cultivars and result in earlier flowering (Heide, 1963). For wild carrot (D. carota), long days can promote premature bolting and flowering; however, we did not find photoperiod information about the annual cultivar Dara. Depending on the available markets among the different seasons, stem length is an important factor when selecting cultivars for specialty cut flower production (Ortiz et al., 2012). Similar to the methods of Ortiz et al. (2012) and Owen et al. (2016), we used $30 \mathrm{~cm}$ as the minimum stem length for marketability. Our results for pot marigold and cockscomb indicated stems harvested in the summer would be more marketable than stems produced in winter. For the three other species, ornamental carrot, strawflower, and stock, they reached marketable stem lengths in summer and winter seasons for greenhouse production.

SeAson: Days to harvest. Days to harvest from sowing differed according to a significant species $\times$ season and year interaction for all species except stock (Fig. 8B). All species had significantly fewer days to harvest in the summer growing seasons, with the exception of stock, which had no differences. Pot marigold, cockscomb, and strawflower days to harvest each significantly differed among all three growing seasons, with the shortest time to harvest in the Summer 2018 season. Pot marigold had a mean of $113.8 \mathrm{~d}$ to harvest in Summer 2018, 172 d in Winter 2018-19, and 126.4 d to harvest in Summer 2019. Cockscomb followed the same pattern $(132.6,192.8$, and $145.3 \mathrm{~d}$, respectively), as did strawflower (120.8, 192.6, and $134 \mathrm{~d}$, respectively). Time to harvest of ornamental carrot was significantly longer in winter compared with the two summer seasons. The mean days to harvest were 123.8 in Summer 2018 and 130.9 in Summer 2019 compared with the winter average, which was $205 \mathrm{~d}$. 
A

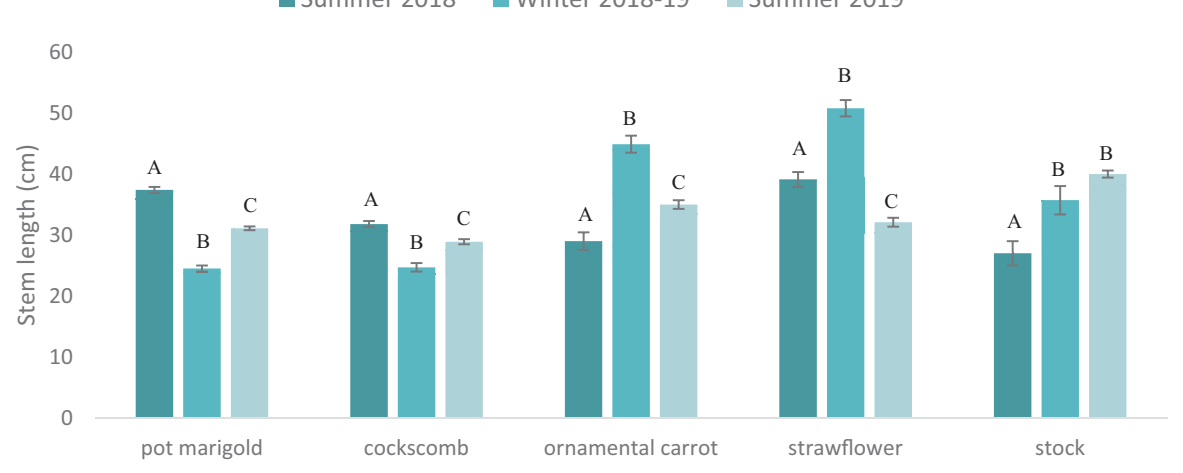

B
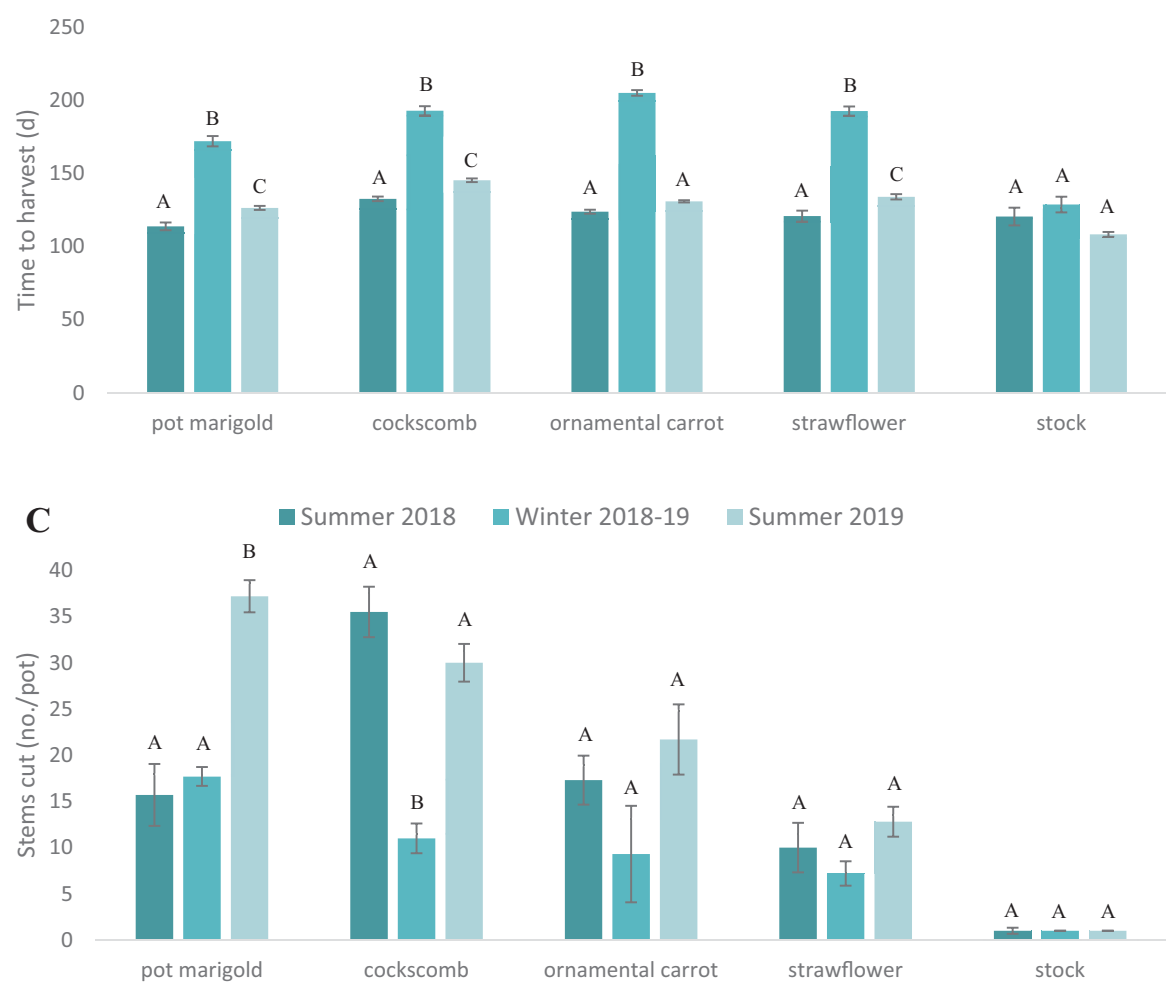

Fig. 8. Mean stem lengths (A), days from seed sowing to harvest (B), and stems cut per plant $(\mathrm{C})$ of cut flower species compared between winter and summer growing seasons in the greenhouse. Error bars represent SE. Mean comparisons were conducted within individual species using pairwise comparisons from Tukey test. Means followed by the same letter are not statistically different at $P \leq 0.05$; $1 \mathrm{~cm}=0.3937$ inch .

Seasonal differences in the time to harvest is an important consideration for growers trying to fill their greenhouse spaces year-round. Earliness to flower and time to harvest are important factors when selecting species (Ortiz et al., 2012). These species all had a reduced time to harvest in the summer as compared with winter; this earlier harvest could result in an earlier return on investment (Owen et al., 2016). However, winter greenhouse production of specialty cut
17.7 stems/plant, respectively). Cockscomb had more stems cut per plant in the two summer growing seasons compared with the winter season. In Summer 2018, an average of 35.5 stems were cut per plant. In Summer 2019, 30 stems were cut per plant. During Winter 2018-19, an average of 11 stems were cut per plant. Ornamental carrot also produced more stems per plant in the summer seasons. In Summer 2018, ornamental carrot produced 17.3 stems/plant. In Summer 2019, it produced 21.7 stems/plant. During Winter 2018-19, an average of 9.3 stems were cut per plant.

Stems cut per plant is another important parameter for cut flower marketability. The average number of stems cut per plant varied across species and seasons. The stems cut per plant communicate yields per square foot based on plant spacing. Spacing will influence the number of flowers and overall quality; containerized crops are recommended at lower densities to increase lateral breaks (Armitage and Dirr, 1995). Spacing may also reveal tradeoffs. Mili and Sable (2003) found that pot marigold spaced on $\approx 1.5-\mathrm{ft}$ centers maximized the number of branches, but that 1 - $\mathrm{ft}$ centers provided maximum plant height in field production.

\section{Marketability}

For each growing season, marketability of the species varied across season and environment (Table 3 ). Marketable yields were driven by a combination of the number of stems harvested and the stem length because stems were considered marketable if they were more than $30 \mathrm{~cm}$. The benefits to each growing environment and season are species-specific. Ornamental carrot had a higher percent of marketable stems in the high tunnels, largely because of longer stem lengths in that environment (Fig. 7A). The percent of marketable strawflower varied according to season, with all stems deemed marketable during the winter season. Marketability was generally higher in the greenhouse, which was in line with the longer stem length in that environment (Fig. 7A). Pot marigold marketability varied between seasons, but stem lengths were longer in the greenhouse (Fig. 7A). The percent of marketable cockscomb varied according to season, with higher marketability 
Table 3. Percent of marketable specialty cut flower stems by environment and season. Marketable yields were calculated by dividing the number of harvested stems $30 \mathrm{~cm}$ (11.8 inches) or more by the total number of cut stems for each species. Percentages for each greenhouse season are from six total plants per species from one block and include stems from both pinched and unpinched plants. The high tunnel percentages come from six plants per species across four blocks for each season, including pinched and unpinched plants. Greenhouse and high tunnels were used for containerized specialty cut flower production. The exception for both of these environments is that stock only had unpinched plants because they did not regrow after pinching treatment.

\begin{tabular}{llccc}
\hline & & \multicolumn{3}{c}{ Marketable cut flower stems (\%) } \\
\cline { 3 - 5 } Species & Environment & $\mathbf{2 0 1 8}$ & $\mathbf{2 0 1 8 - 1 9}$ & $\mathbf{2 0 1 9}$ \\
\hline Pot marigold & Greenhouse & 97.9 & 21.7 & 66.8 \\
& High tunnels & 83.7 & - & 50.5 \\
Cockscomb & Greenhouse & 63.9 & 22.7 & 48.3 \\
& High tunnels & 39.5 & - & 36.6 \\
Ornamental carrot & Greenhouse & 42.3 & 92.9 & 75.4 \\
\multirow{2}{*}{ Strawflower } & High tunnels & 84.2 & - & 90.8 \\
& Greenhouse & 85.0 & 100.0 & 71.4 \\
Stock & High tunnels & 71.6 & - & 60.5 \\
& Greenhouse & 0.0 & 100.0 & 100.0 \\
& High tunnels & 27.3 & - & 54.5 \\
\hline
\end{tabular}

occurring in the summer growing seasons. Stock produced one stem per plant and may be used more successfully with a successional planting schedule.

\section{Conclusions}

The resurgence of locally grown goods has been an added boost to the horticulture industry in Wyoming. The spread and popularity of farmers' markets, community-supported agriculture shares, and food cooperatives around the state are a strong sign of this trend. Fresh cut flowers are feasible for the Wyoming climate with both high-tunnel and greenhouse production. Most of the species used in this study were successfully cultivated in both growing environments throughout the year in Laramie, WY. The exception in successful production was seen with the challenges faced in producing stock because it did not continue to produce after being cut. Stock produced marketable stems in both environments, but different production practices need to be explored, such as tighter spacing for maximum stems per square foot and succession planting (Johnny's Selected Seeds, 2016). Generally, greenhouse conditions provided a longer duration of harvest and an earlier first harvest date, with a few exceptions, most likely because of greater climate control and less exposure to environmental conditions such as wind, temperature variations, and rain. Although flowers inside of the high tunnel were generally protected from environmental conditions, sides were open up to $\approx 3 \mathrm{ft}$ from the ground level on both sides, allowing exposure to some elements.

Best production practices for growing pot marigold would be either high tunnels or a controlled greenhouse environment during the summer months. Greenhouse production of cockscomb is recommended instead of high tunnels; stems from plants in the high tunnels may be too short depending on the market. Ornamental carrot was successfully grown in both environments and seasons, but it took longer to produce during the winter in the greenhouse. Strawflower did well in the greenhouse in both growing seasons and can be grown in the summer months in high tunnels. Pinching can be a labor-intensive process and did not show any differences; therefore, it can be eliminated from the production

At the time of the first summer season, the cut flowers were sold to the student farm at the University of Wyoming, where they were incorporated into community-supported agriculture shares and sold at the local Downtown Farmers Market. The second summer season flowers were sold to a local Laramie florist, who sold them in arrangements and used them in university events. The markets are process for these species. available for the successful integration of this commodity into existing operations. The local demand and the type of operation will help indicate best production practices and species selection. The findings from this research can provide recommendations for producers who are trying new species and production practices that are suitable for their businesses.

\section{Literature cited}

Armitage, A.M. and M.A. Dirr. 1995. Influence of spacing on yield of Buddleia and Salix grown as cut flowers and stems. J. Environ. Hort. 13(4):176-177, https:// doi.org/10.24266/0738-2898-13.4.176.

Armitage, A.M. and J.M. Laushman. 2008. Specialty cut flowers: The production of annuals, perennials, bulbs and woody plants for fresh and dry cut flowers. Varsity Press, Portland, OR.

Bonarriva, J. 2003. Industry \& trade summary: Cut flowers. U.S. Intl. Trade Commission Publ. 3580. <https://www.usitc. gov/publications/332/pub3580.pdf $>$.

Chopde, N., J.G. Jadhav, and M.H. Bhande. 2015. Response of calendula to plant density for cut flower production. Plant Arch. 15(2):657-660.

Clark, E.M.R, J.M. Dole, A.S. Carlson, E.P. Moody, I.F. McCall, F.L. Fanelli, and W.C. Fonteno. 2010. Vase life of new cut flower cultivars. HortTechnology 20(6): 1016-1025, https://doi.org/10.21273/ HORTSCI.20.6.1016.

Curtis, J. and K. Grimes. 2004. Wyoming climate atlas. Water Resources Data System and State Climate Office, Laramie, WY.

Dole, J.M. and H.F. Wilkins. 1999. Floriculture: Principles and species. Prentice Hall, Upper Saddle River, NJ.

Dole, J.M., I. McCall, and J.M. Laushman. 2016. The latest field grown cut flowers. 17 Oct. 2020. <https://gpnmag.com/article/ the-latest-field-grown-cut-flowers $/>$.

Garfinkel, A.R. and K.L. Panter. 2014. Yearround greenhouse production of cut sunflowers in the Rocky Mountain West. HortTechnology 24(6):743-748, https://doi. org/10.21273/HORTTECH.24.6.743.

Heide, O.M. 1963. Juvenile phase and flower initiation in brilliant stocks (Matthiola incana R.Br.). J. Hort. Sci. 38(1):4-14, https://doi.org/10.1080/00221589.1963. 11514053.

Jauron, R. 2003. Harvesting everlasting flowers for drying. 16 Mar. 2020. <https:// hortnews.extension.iastate.edu/2003/6-272003/everlast.html\#: :text=Strawflower\%20 
(Helichrysum\%20bracteatum)\%20Harvest $\% 20$ when,22\%2Dgauge $\% 20$ wire $\% 20$ before $\% 20$ drying $>$.

Johnny's Selected Seeds. 2016. Stock production. 18 Mar. 2021. <https://www. johnnyseeds.com/on/demandware.static//Library-Sites-JSSSharedLibrary/default/ dw962d679a/assets/information/stockproduction.pdf $>$.

Kaiser, C. and M. Ernst. 2016. Greenhousegrown specialty cut flowers. 29 Sept. 2020. <https://www.uky.edu/ccd/sites/www. uky.edu.ccd/files/ghcutflowers.pdf $>$.

Koch, D. 1996. Field grown cut flowers. Ministry Agric. Fisheries Food Floriculture Factsheet File No. 400-07.

Lamont, W.J. Jr. 2009. Overview of the use of high tunnels worldwide. HortTechnology 19(1):25-29, https://doi.org/ 10.21273/HORTSCI.19.1.25.

Mili, R. and A.S. Sable. 2003. Effect of planting density and nitrogen levels on growth and flower production of calendula
(Calendula officinalis L.). Indian J. Hort. 60(4):343-345.

Ortiz, M.A., K. Hyrczyk, and R.G. Lopez. 2012. Comparison of high tunnel and field production of specialty cut flowers in the Midwest. HortScience 47(9):1265-1269, https://doi.org/10.21273/HORTSCI.47. 9.1265 .

Owen, W.G., A. Hilligoss, and R.G. Lopez. 2016. Late-season high tunnel planting of specialty cut flowers in the midwestern United States influences yield and stem quality. HortTechnology 26(3):338-343, https://doi.org/10.21273/HORTTECH. 26.3.338.

Panter, K.L., T.M Gergeni, C.P. Seals, and A.R. Garfinkel. 2019. Orientation of small hobby high tunnels and potential effects on cut sunflowers and fresh herbs. HortTechnology 29(4):461-467, https://doi.org/ 10.21273/HORTTECH04273-19.

Torres, A.P. and R.G. Lopez. 2010. Measuring daily light integral in a greenhouse.
9 Nov. 2020. <http://www.extension. purdue.edu/extmedia/HO/HO-238-W. pdf $>$.

Verlinden, S. and L. McDonald. 2007. Productivity and quality of statice (Limonium sinuatum cv. Soiree $\mathrm{Mix}$ ) and cockscomb (Celosia argentea cv. Chief Mix) under organic and inorganic fertilization regiments. Sci. Hort. 114(3): 199-206, https://doi.org/10.1016/j. scienta.2007.06.011.

Wien, H.C. 2008. The 2008 cut flower trials. Department of Horticulture, Cornell University, Ithaca, NY.

Wien, H.C. 2009 Floral crop production in high tunnels. HortTechnology 19(1):5660, https://doi.org/10.21273/HORTSCI. 19.1.56.

Wien, H.C. and M.P. Pritts. 2009. Use of high tunnels in the northern USA: Adaption to cold climates. Acta Hort. 807:5559, https://doi.org/10.17660/ActaHortic. 2009.807.3. 